\title{
FIXED-BED ADSORPTION OF CEPHALEXIN ONTO WALN UT SHELL-BASED ACTIVATED CARBON
}

\author{
Ghadir Nazari ${ }^{1}$, Hossein Abolghasemi ${ }^{1,2, *}$, Mohamad Esmaieli ${ }^{1}$
}

https://doi.org/10.23939/chcht11.02.253

\begin{abstract}
In this work activated carbon (AC) was used for the removal of cephalexin (CFX) from aqueous solution in a fixed-bed column. The breakthrough curves of the adsorption process of CFX on the walnut shell AC at different mass of the adsorbent, flow rate and initial CFX concentration were determined.
\end{abstract}

Keywords: cephalexin adsorption, fixed-bed column, walnut shell, physical activation, activated carbon.

\section{Introduction}

Nowadays, a large amount of pharmaceuticals is produced and used in the human and veterinary medical practices, aquaculture and agricultural products. The extensive use of pharmaceuticals has led to the continual release of a wide range of pharmaceutical chemicals into our environment. Major methods used in the removal of pharmaceuticals from wastewater include adsorption [1], ozonation and biomembrane [2], biological filtration [3], and reverse osmosis [4]. Removal of pharmaceuticals from wastewater is largely dependent on their physical and chemical properties, their reactivity towards different treatment processes and process control, such as solids retention time, temperature and hydraulic retention time, and treatment processes can therefore achieve some level of removal [5]. In this regard, adsorption is a simple and effective method that can be used as an efficient method in removal of pharmaceuticals from aqueous solution. Cephalexin (CFX) is the most widely used cephalosporin antibiotic with an annual use of 3,000 tons and annual sales revenue of $\$ 850,000,000$ [6]. Due to the prevalence of their respective antibiotic family usage, cephalexin was selected. For the removal of CFX from aqueous solution, activated carbon (AC) [7-10], bentonite [11], and

\footnotetext{
${ }^{1}$ University of Tehran, College of Engineering, School of Chemical Engineering

Center for Separation Processes Modeling, P.O.Box 11365-4563, Tehran, Iran

${ }^{2}$ University of Tehran, Oil and Gas Center of Excellence, Tehran, Iran

*hoap@ut.ac.ir

(C) Nazari G., Abolghasemi H., Esmaieli M., 2017
}

polymeric resins [12] were applied. Natural adsorbents due to being inexpensive are widely used as the precursor of AC. In this work, walnut shell as a low-cost material is used to produce $\mathrm{AC}$ by using physical activation. Other natural adsorbents such as almond shell [13], palm shell [14], rice husk [15], and rice husk [16] have also been proposed for the production of AC. In this study, the performance of the walnut shell AC for the removal of CFX in a fixed-bed column is investigated. Then, the modeling of the fixed-bed adsorption dynamics is presented and the model parameters are calculated.

\section{Experimental}

\subsection{M aterials}

Cephalexin monohydrate [(7R)-7-(D- $\alpha$-amino- $\alpha$ phenylacetamido)-3-methyl-3-cephem-4-carboxylic acid hydrate] (purity $>99.8 \%$ ) as an adsorbate was obtained as a gift sample from LOGHMAN Pharmaceutical \& Hygienic Co., Tehran, Iran. Its chemical formula is $\mathrm{C}_{16} \mathrm{H}_{17} \mathrm{~N}_{3} \mathrm{O}_{4} \mathrm{~S}(M W=347.6 \mathrm{~g} / \mathrm{mol})$, and $\lambda_{\max }=263 \mathrm{~nm}$. The molecular structure of CFX is illustrated in Fig. 1.

\subsection{Preparation and Characterization of $A C$}

The adsorbent was prepared from physical activation of walnut shell that described by P. Nowicki et al. [17]. It was found that the specific surface area, average pore diameter and total pore volume of the walnut shell AC were $161.3 \mathrm{~m}^{2} \cdot \mathrm{g}^{-1}, 1.94 \mathrm{~nm}$ and $0.14 \mathrm{~cm}^{3} \cdot \mathrm{g}^{-1}$, respectively. The SEM analysis of prepared AC, before and after adsorption, is shown in Fig. 2.

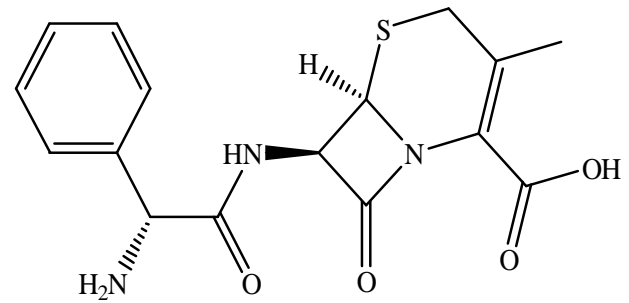

Fig. 1. The chemical structure of cephalexin (CFX) 

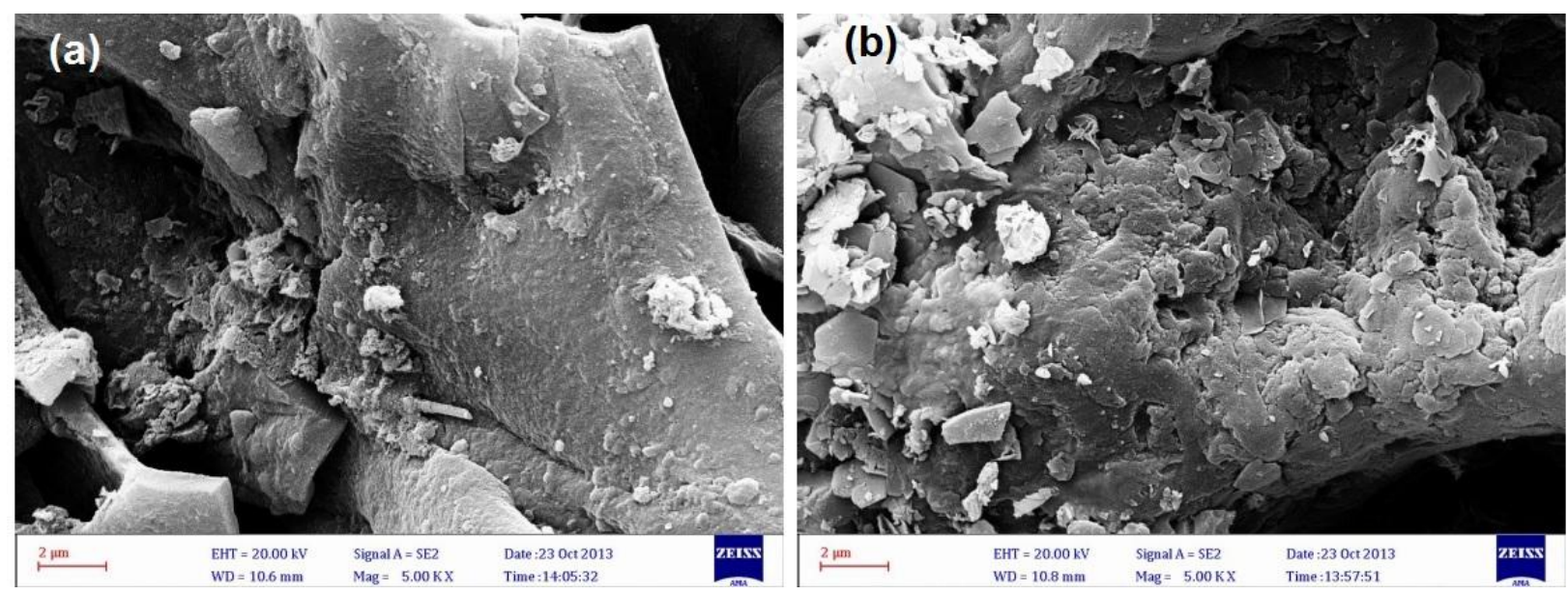

Fig. 2. The SEM analysis of walnut shell AC before (a) and after (b) adsorption

\subsection{Experimental Setup}

The column experiments were conducted in a Pyrex glass tube with an internal diameter of $1.4 \mathrm{~cm}$ and a height of $20 \mathrm{~cm}$. The adsorbent was supported by glass wool on the top and also the bottom of the bed to ensure good liquid distribution in the column. The column was packed with 6,8 and $10 \mathrm{~g}$ of walnut shell $\mathrm{AC}$ (equivalent to 12,16 and $20 \mathrm{~cm}$ of the bed height) at $303 \mathrm{~K}$ and $\mathrm{pH}=6$. The CFX solution of known concentration (30, 70 and $100 \mathrm{mg} / \mathrm{l})$ was channeled into the column using a peristaltic pump at the favorite flow rate $(4.5,6$ and $7.5 \mathrm{ml} / \mathrm{min}$ ). The CFX solution at the outlet of the column was collected at regular time to determine the remaining CFX concentration using a UV-vis spectrophotometer (UNICAM, 8700 series, USA) at $\lambda_{\max }=263 \mathrm{~nm}$.

\subsection{Fixed-Bed Data Analysis}

The breakthrough curves are usually expressed by the ratio of effluent CFX concentration to influent CFX concentration $\left(C_{t} / C_{0}\right)$ as a function of time or volume of the effluent for a given bed height. The effluent volume, $V_{\text {eff }}(\mathrm{ml})$, can be calculated by Eq. (1) [18]:

$$
V_{\text {eff }}=Q t_{\text {total }}
$$

where $Q$ and $t_{\text {total }}$ are the volumetric flow rate $(\mathrm{mL} / \mathrm{min})$ and total flow time (min), respectively. The value of the total mass of CFX adsorbed, $q_{\text {total }}(\mathrm{mg})$, can be calculated from the area under the breakthrough curve that can be written by Eq. (2).

$$
\begin{aligned}
q_{\text {total }} & =\frac{Q A}{1000}=\frac{Q}{1000} \int_{t=0}^{t=t_{\text {total }}} C_{a d} d t= \\
& =\frac{Q}{1000} \int_{t=0}^{t=t_{\text {total }}}\left(C_{0}-C_{t}\right) d t
\end{aligned}
$$

The amount of equilibrium CFX uptake or the maximum capacity of the column, $q_{e q}(\mathrm{mg} / \mathrm{g})$, in the column is calculated as the following:

$$
q_{e q}=\frac{q_{\text {total }}}{W}
$$

where $W$ is the dry weight of adsorbent in the column, $\mathrm{g}$. The total amount of CFX ( $\left.m_{\text {total }}\right)$ sent through the column is calculated from Eq. (4):

$$
m_{\text {total }}=\frac{C_{0} Q t_{\text {total }}}{1000}
$$

The removal percentage $(Y)$ of CFX can be obtained from Eq. (5):

$$
Y=\frac{q_{\text {total }}}{m_{\text {total }}} \cdot 100
$$

The flow rate represents the empty bed contact time (EBCT) in the column given as:

$$
E B C T(\mathrm{~min})=\text { volume }(\mathrm{ml}) / \text { flow rate }(\mathrm{ml} / \mathrm{min})
$$

\section{Results and Discussion}

\subsection{Batch Study}

$50 \mathrm{ml}$ of CFX solution of different initial concentrations $(40,60,80,100$, and $120 \mathrm{mg} / \mathrm{l})$ were mixed with $0.45 \mathrm{~g}$ of walnut shell $\mathrm{AC}$ in $100 \mathrm{ml}$ Erlenmeyer flasks. The amount of CFX adsorbed onto walnut shell $\mathrm{AC}\left(q_{e}\right)$ can be calculated as below:

$$
q_{e}=\frac{\left(C_{0}-C_{e}\right) \cdot V}{W}
$$

where $C_{0}$ and $C_{e}$ are the initial and the equilibrium concentrations of CFX ( $\mathrm{mg} / \mathrm{l})$, respectively, $V(\mathrm{l})$ is the volume of the solution, $W(\mathrm{~g})$ is the mass of adsorbent. The optimum walnut shell AC dose was $0.45 \mathrm{~g}$ per $50 \mathrm{ml}$ of CFX solution. The adsorption equilibrium isotherm of CFX on the walnut shell AC was prepared; it is shown in Fig. 3. 


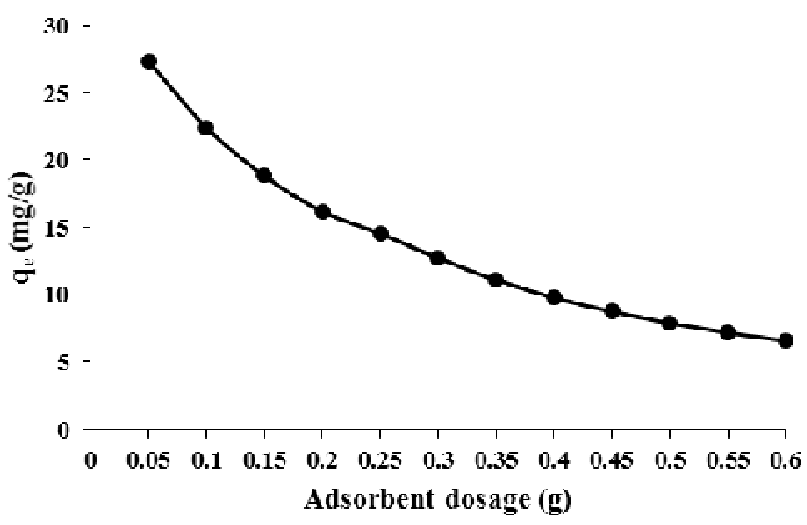

Fig. 3. The equilibrium adsorption isotherm of CFX on the walnut shell $\mathrm{AC}$

In Fig. 3, we can see a gradual decrease in the slope of adsorption isotherm, which can be ascribed to the fact that the monolayer, sited in the surface of the adsorbent, have been saturated. In the present work, the Langmuir and Freundlich isotherm models, two classic adsorption models, were used to describe the adsorption equilibrium. The linear form of the Langmuir and Freundlich models are given below, respectively:

$$
\begin{gathered}
\frac{C_{e}}{q_{e}}=\frac{C_{e}}{q_{m}}+\frac{1}{K_{L} q_{m}} \\
\ln q_{e}=\ln K_{F}+\frac{1}{n} \ln C_{e}
\end{gathered}
$$

where $q_{m}$ is the theoretical maximum adsorption capacity per unit mass of the adsorbent, $\mathrm{mg} \cdot \mathrm{g}^{-1} ; K_{L}$ and $K_{F}$ are the adsorption constants of the Langmuir and Freundlich models, respectively, and $n$ is the Freundlich linearity index. The model parameters and the correlation coefficients are listed in Table 1. It can be seen that the best fitting of experimental data was achieved by the Freundlich isotherm model.

\subsection{Fixed-Bed Breakthrough Curves at Different Flow Rates}

Fig. 4 shows the effect of flow rate on the breakthrough curves at different flow rates $(4.5,6$ and $7.5 \mathrm{ml} / \mathrm{min}$ ) resulted from the adsorption of $\mathrm{CFX}$ on walnut shell AC with the initial CFX concentration of $70 \mathrm{mg} / \mathrm{l}$, and at a constant mass of the adsorbent of $8 \mathrm{~g}$. As can be seen from Fig. 4, in the case of $7.5 \mathrm{ml} / \mathrm{min}$, a more rapid removal of CFX in the initial step and the rate decreased thereafter to finally reach saturation. As volumetric flow rate increased, the breakthrough curve became steeper and reached saturation more quickly. This means that the contact time between the walnut shell AC and CFX is lower, leading to lower breakthrough and saturation times [19]. The parameters in fixed-bed column for CFX adsorption by walnut shell AC are presented in
Table 2. The breakthrough time $t_{b}$ decreased from 6.7 to $2.8 \mathrm{~min}$ when the flow rate enhanced from 4.5 to $7.5 \mathrm{ml} / \mathrm{min}$, which is due to the fact that the contact time between CFX ions and adsorbent at higher flow rate of CFX solution has decreased [20]. According to Table 2, as flow rate increased from 4.5 to $7.5 \mathrm{ml} / \mathrm{min}$, the value of the total mass of CFX adsorbed dropped from 81.9 to $47.3 \mathrm{mg} / \mathrm{g}$. The results are entirely in agreement with the results of other studies given elsewhere [21, 22].

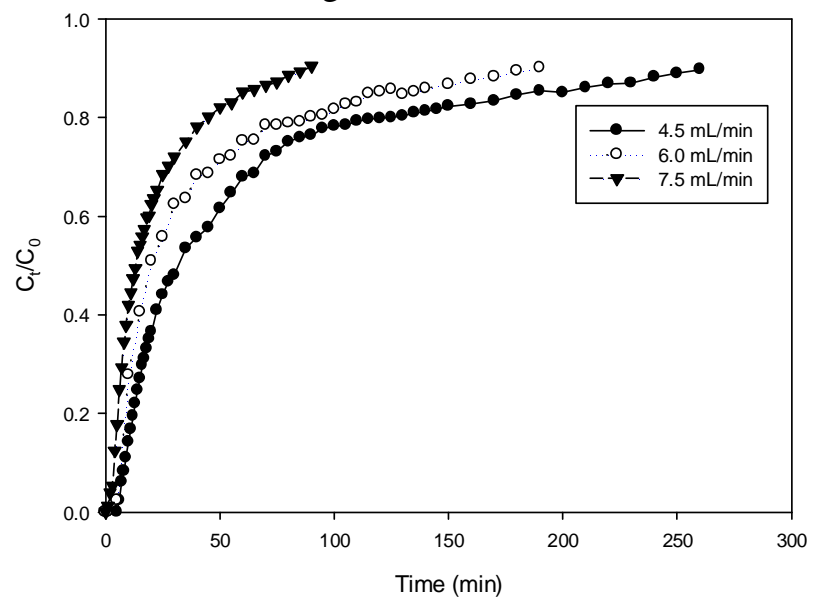

Fig. 4. The breakthrough curve of CFX sorption at different flow rates

\subsection{Fixed-Bed Breakthrough Curves at Different Influent CFX Concentrations}

The effect of influent CFX concentration on CFX adsorption by the walnut shell $\mathrm{AC}$ was investigated at different initial CFX concentration (30, 70 and $100 \mathrm{mg} / \mathrm{l})$. The results are shown in Fig. 5. As demonstrated in Fig. 5, the breakthrough curves became steeper as the initial concentration increases. The breakthrough time $t_{b}$ decreases from 15.3 to $3.8 \mathrm{~min}$ when the initial concentration increases from 30 to $100 \mathrm{mg} / \mathrm{l}$. The reason can be a quick saturation of the available binding sites for CFX. The slow transport of CFX onto walnut shell AC is due to lower concentration gradient leads to a slower breakthrough curve [23]. The parameters in fixed-bed column for CFX adsorption by walnut shell AC are presented in Table 2. As shown in Table 2, the removal efficiency of CFX ions had an increasing trend in column with the decrease in the influent CFX concentration. With the increase in influent CFX concentration from 30 to $100 \mathrm{mg} / \mathrm{l}$, the uptake and corresponding total CFX adsorbed were found to increase from 1.78 to $2.17 \mathrm{mg} / \mathrm{g}$ and 25.3 to $33 \mathrm{mg}$, respectively (Table 2). This trend may be due to higher driving force gradient in the higher influent CFX concentration to overcome the mass transfer resistance [24]. The highest removal efficiency $(Y=56.5 \%)$ was obtained for the inlet CFX concentration of $30 \mathrm{mg} / \mathrm{l}$. Accordingly, adsorption antibiotic is more favorable in lower concentration. 
Table 1

The Langmuir and Freundlich adsorption isotherms parameters

\begin{tabular}{|c|c|c|c|c|c|}
\hline \multicolumn{3}{|c|}{ Langmuir } & \multicolumn{3}{c|}{ Freundlich } \\
\hline$q_{m}, \mathrm{mg} \cdot \mathrm{g}^{-1}$ & $k_{L}, \mathrm{l} \cdot \mathrm{mg}^{-1}$ & $R^{2}$ & $k_{F}, 1 \cdot \mathrm{mg}^{-1}$ & $n$ & $R^{2}$ \\
\hline 37.3 & 2.673 & 0.9881 & 24.76 & 5.71 & 0.9931 \\
\hline
\end{tabular}

Table 2

Operation conditions and results

for the fixed-bed column experiments $(T=303 \mathrm{~K}$ and $\mathbf{p H}=6)$

\begin{tabular}{|c|c|c|c|c|c|c|c|c|c|}
\hline$C_{0}, \mathrm{mg} / \mathrm{g}$ & $Q, \mathrm{ml} / \mathrm{min}$ & $m, \mathrm{~g}$ & $t_{b}, \mathrm{~min}$ & $V_{\text {eff, }} \mathrm{ml}$ & $m_{\text {total }}, \mathrm{mg}$ & $q_{\text {total }}, \mathrm{mg}$ & $q_{e}, \mathrm{mg} / \mathrm{g}$ & $Y, \%$ & $E B C T$ \\
\hline 30 & 6 & 8 & 15.3 & 840 & 25.3 & 14.3 & 1.78 & 56.5 & 2.1 \\
\hline 70 & 6 & 8 & 5.5 & 480 & 29.4 & 16.1 & 2.01 & 54.8 & 2.1 \\
\hline 100 & 6 & 8 & 3.8 & 330 & 33.0 & 17.4 & 2.17 & 52.7 & 2.1 \\
\hline 70 & 4.5 & 8 & 6.7 & 1170 & 81.9 & 59.4 & 7.42 & 72.5 & 2.8 \\
\hline 70 & 6 & 8 & 5.5 & 1140 & 79.8 & 57.0 & 7.12 & 71.4 & 2.1 \\
\hline 70 & 7.5 & 8 & 2.8 & 675 & 47.3 & 33.2 & 4.15 & 70.2 & 1.7 \\
\hline 70 & 6 & 6 & 5.5 & 660 & 46.2 & 17.4 & 2.90 & 37.7 & 1.5 \\
\hline 70 & 6 & 8 & 8.6 & 840 & 58.8 & 23.2 & 2.90 & 39.6 & 2.1 \\
\hline 70 & 6 & 10 & 13.3 & 930 & 66.1 & 27.8 & 2.78 & 42.1 & 2.6 \\
\hline
\end{tabular}

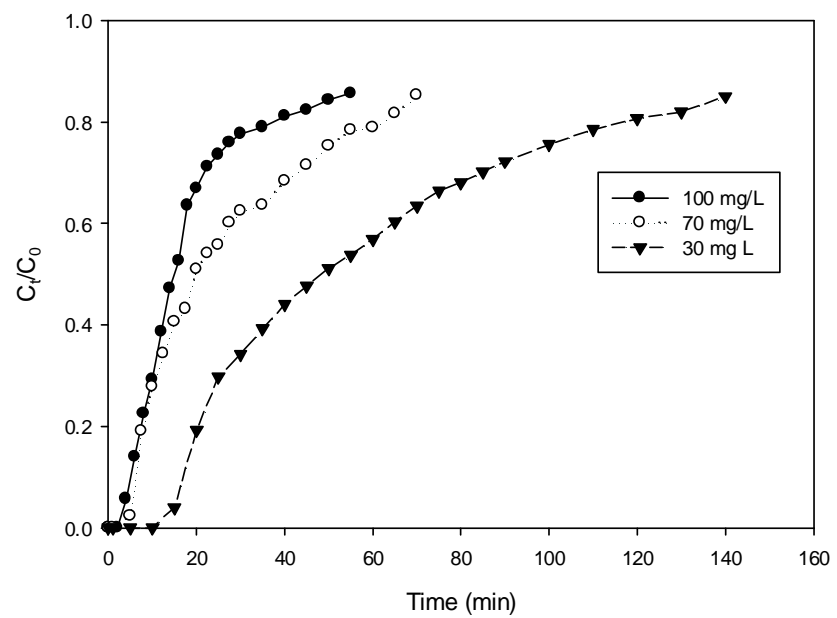

Fig. 5. The breakthrough curve of CFX sorption at different concentrations

\subsection{Fixed-Bed Breakthrough Curves at Different Mass of the Adsorbent}

The adsorption of CFX in the fixed-bed column is largely dependent on the mass of the adsorbent, directly proportional to the quantity of walnut shell $\mathrm{AC}$ in the column. Fig. 6 shows the breakthrough curve of CFX sorption at different mass of the adsorbent. The parameters in fixed-bed column for CFX adsorption by walnut shell AC are presented in Table 2. From Fig. 6, it is observed that as the mass of adsorbent increased, both the exhaustion time and effluent volume $V_{\text {eff }}$ increased. With the increase in the mass of adsorbent, the $V_{\text {eff }}$ increased, which might be due to the more contact time

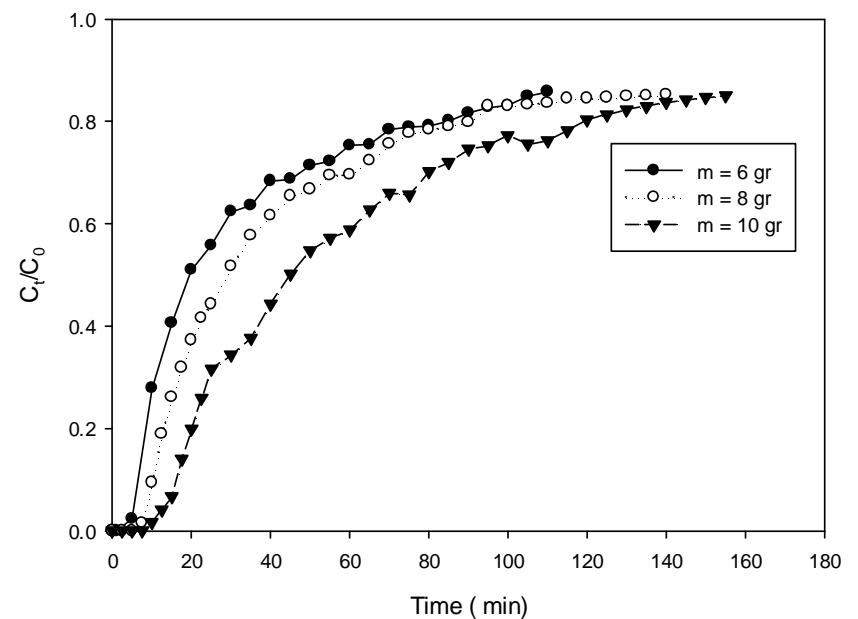

Fig. 6. The breakthrough curve of CFX sorption at different mass of the adsorbent

between the adsorbent and the adsorbate [24]. As observed in Table 2, when the mass of adsorbent was enhanced to $10 \mathrm{~g}$, exhaustion time increased. The EBCT also increased from 1.5 to $2.6 \mathrm{~min}$ with the mass of adsorbent increasing from 6 to $10 \mathrm{~g}$. These results indicated that the lower mass of adsorbent $(6 \mathrm{~g})$ offered an optimum breakthrough curve. The total surface area was increased with increasing the mass of the adsorption. Despite this, the maximum capacity $q_{e q}$ of CFX on the walnut shell $\mathrm{AC}$ adsorption sites was low because not all the surface walnut shell $\mathrm{AC}$ were accessible to $\mathrm{CFX}$ molecules [25]. Accordingly, a relatively low mass of the adsorbent was beneficial to antibiotics adsorption, which agrees with the result obtained by Chen et al. [21]. 


\subsection{Breakthrough Curve Modelling}

Breakthrough curves unveil the concentration profiles in a fixed-bed column. Several simple mathematical models have been developed for describing and analyzing the column experimental data. In this study, four mathematical models have been proposed to predict the breakthrough curves. The suggested models are presented as follows [26]:

$$
\begin{aligned}
& \operatorname{Model}(1): \frac{C_{t}}{C_{0}}=1+\left(C_{1}+C_{2} t^{C_{3}}\right) \exp \left(-\mathrm{C}_{4} \mathrm{t}\right) \\
& \operatorname{Model}(2): \frac{C_{t}}{C_{0}}=1+\left(C_{1}+C_{2} t+C_{3} t^{2}\right) \exp \left(-\mathrm{C}_{4} \mathrm{t}\right) \\
& \operatorname{Model~(3):} \frac{C_{t}}{C_{0}}=1+\left(C_{1}+C_{2} t+C_{3} t^{C_{4}}\right) \exp \left(-\mathrm{C}_{5} \mathrm{t}\right) \\
& \text { Model (4): } \frac{C_{t}}{C_{0}}=1+\left(C_{1}+C_{2} t+C_{3} t^{C_{4}}\right) \exp \left(-\mathrm{C}_{5} \mathrm{t}^{C_{6}}\right)
\end{aligned}
$$

The mentioned models include the multiple of a multivariable function and an exponential function for the purpose of enabling the models predicting the breakthrough curves of the axially-dispersed plug flow adsorption processes. This type of modelling of the breakthrough curves has been reported and used by other researchers [27]. For validation of these models the correlation coefficient $\left(R^{2}\right)$, adjusted coefficient of determination $\left(A R^{2}\right)$ and the residual sum of squares $(R S S)$ were used. The mathematical formula of RSS is:

$$
R S S=\sum_{i=1}^{n}\left(y_{i}-F\left(x_{i}\right)\right)^{2}
$$

where $y_{i}$ is the $i^{\text {th }}$ value of the variable to be predicted, $x_{i}$ is the $i^{\text {th }}$ value of the explanatory variable, and $F\left(x_{i}\right)$ is the predicted value of $y_{i}$. The correlation and modelling constants have been determined with respect to O.L.S. method by using Eviews software and are presented in Tables 3-5. It can be seen from Table 3 that the model (2) has high values of $\mathrm{R}^{2}$, adjusted- $\mathrm{R}^{2}$ and the minimum of RSS for the fixed-bed adsorption column at different flow rates. The model (2) and (4) were the best models that fitted the experimental column data at various influent concentrations (Table 4). It can be seen from Table 5 that all of the models except model (1) were appropriate for describing the adsorption behavior for the adsorption of

\begin{tabular}{|c|c|c|c|c|c|c|c|c|c|c|}
\hline Model & $\mathrm{Q}, \mathrm{ml} / \mathrm{min}$ & $C_{1}$ & $C_{2}$ & $C_{3}$ & $C_{4}$ & $C_{5}$ & $C_{6}$ & $R^{2}$ & $A R^{2}$ & $R S S$ \\
\hline Model 1 & 4.5 & 7.53 & -8.47 & -0.0005 & 0.0147 & - & - & 0.9470 & 0.9440 & 0.2593 \\
\hline Model 1 & 6.0 & 26.48 & -27.35 & -0.0003 & 0.0178 & - & - & 0.9160 & 0.9079 & 0.1832 \\
\hline Model 1 & 7.5 & 27.80 & -28.78 & $-7.66^{*} 10^{-5}$ & 0.0434 & - & - & 0.9599 & 0.9564 & 0.1137 \\
\hline Model 2 & 4.5 & -1.07 & 0.0111 & -0.0001 & 0.0153 & - & - & 0.9947 & 0.9944 & 0.0259 \\
\hline Model 2 & 6.0 & -1.04 & 0.0155 & -0.0002 & 0.0229 & - & - & 0.9913 & 0.9904 & 0.0189 \\
\hline Model 2 & 7.5 & -1.04 & 0.0148 & $-3.05 * 10^{-5}$ & 0.0404 & - & - & 0.9959 & 0.9955 & 0.0115 \\
\hline Model 3 & 4.5 & -1.1115 & -0.9670 & 1.0033 & 0.9932 & 0.0091 & - & 0.9916 & 0.9909 & 0.0409 \\
\hline Model 3 & 6.0 & -1.067 & -1.2917 & 1.3388 & 0.9927 & 0.0145 & - & 0.9879 & 0.9863 & 0.0263 \\
\hline Model 3 & 7.5 & -1.0913 & -2.3485 & 2.4154 & 0.9940 & 0.0231 & - & 0.9918 & 0.9908 & 0.0231 \\
\hline Model 4 & 4.5 & -114.40 & -0.3567 & 21.211 & 0.3992 & 4.4122 & -0.0039 & 0.9866 & 0.9853 & 0.0652 \\
\hline Model 4 & 6.0 & -94.405 & -0.1927 & 32.167 & 0.2571 & 4.0700 & -0.0059 & 0.9813 & 0.9781 & 0.0406 \\
\hline Model 4 & 7.5 & -0.9208 & -2.2847 & 2.3527 & 0.9943 & -0.1203 & 0.0091 & 0.9891 & 0.9858 & 0.0593 \\
\hline
\end{tabular}
CFX onto walnut shell AC in a fixed-bed column at different mass of the adsorbent.

Table 3

The parameters of the adsorption dynamic models for various flow rates

Table 4

The parameters of the adsorption dynamic models for different influent CFX concentration

\begin{tabular}{|c|c|c|c|c|c|c|c|c|c|c|}
\hline Model & $\mathrm{C}_{0}, \mathrm{mg} / \mathrm{l}$ & $C_{1}$ & $C_{2}$ & $C_{3}$ & $C_{4}$ & $C_{5}$ & $C_{6}$ & $R^{2}$ & $A R^{2}$ & $R S S$ \\
\hline Model 1 & 30 & 14.472 & -15.482 & $-6.03 \mathrm{E}-06$ & 0.0120 & - & - & 0.9691 & 0.9662 & 0.0784 \\
\hline Model 1 & 70 & 14.534 & -15.420 & -0.0004 & 0.0190 & - & - & 0.9218 & 0.9128 & 0.1529 \\
\hline Model 1 & 100 & -0.9882 & -0.1342 & 0.3855 & 0.0612 & - & - & 0.9738 & 0.9709 & 0.0694 \\
\hline Model 2 & 30 & -1.0691 & 0.0042 & $-4.03 \mathrm{E}-05$ & 0.0124 & - & - & 0.9848 & 0.9834 & 0.0384 \\
\hline Model 2 & 70 & -1.0503 & 0.0152 & -0.0002 & 0.0243 & - & - & 0.9908 & 0.9897 & 0.0179 \\
\hline Model 2 & 100 & -1.1092 & 0.0441 & -0.0005 & 0.0025 & - & - & 0.9865 & 0.9839 & 0.0621 \\
\hline Model 3 & 30 & -0.9594 & -0.0740 & $-1.62 \mathrm{E}-10$ & 5.7339 & 0.0514 & - & 0.9781 & 0.9753 & 0.0555 \\
\hline Model 3 & 70 & -0.9811 & -0.0909 & $-1.87 \mathrm{E}-09$ & 5.8037 & 0.0844 & - & 0.9599 & 0.9534 & 0.0785 \\
\hline Model 3 & 100 & -0.9851 & -0.1534 & $-1.08 \mathrm{E}-08$ & 5.8019 & 0.1236 & - & 0.9978 & 0.9975 & 0.0056 \\
\hline Model 4 & 30 & -6.7334 & 531300.3 & -757786.2 & 1.1695 & 12.356 & 0.1014 & 0.9881 & 0.9861 & 0.0302 \\
\hline Model 4 & 70 & -5.8550 & 531320.0 & -757781.2 & 1.1247 & 12.316 & 0.1054 & 0.9931 & 0.9916 & 0.0134 \\
\hline Model 4 & 100 & -3.4528 & 510936.0 & -767755.7 & 1.3582 & 12.525 & 0.1256 & 0.9821 & 0.9665 & 0.0739 \\
\hline
\end{tabular}


The parameters of the adsorption dynamic models for different mass of the adsorbent

\begin{tabular}{|c|c|c|c|c|c|c|c|c|c|c|}
\hline Model & $\mathrm{W}, \mathrm{g}$ & $C_{1}$ & $C_{2}$ & $C_{3}$ & $C_{4}$ & $C_{5}$ & $C_{6}$ & $R^{2}$ & $A R^{2}$ & $R S S$ \\
\hline Model 1 & 6.0 & -1.0579 & 0.1010 & 0.3961 & 0.0129 & - & - & 0.9596 & 0.9535 & 0.0693 \\
\hline Model 1 & 8.0 & -1.0798 & 0.0372 & 0.5185 & 0.0152 & - & - & 0.9695 & 0.9664 & 0.0893 \\
\hline Model 1 & 10.0 & -1.0750 & 0.0015 & 0.8096 & 0.0144 & - & - & 0.9852 & 0.9839 & 0.0505 \\
\hline Model 2 & 6.0 & -1.0527 & 0.0135 & -0.0002 & 0.0271 & - & - & 0.9896 & 0.9880 & 0.0178 \\
\hline Model 2 & 8.0 & -1.0923 & 0.0127 & $-9.61 \mathrm{E}-05$ & 0.0149 & - & - & 0.9898 & 0.9888 & 0.0296 \\
\hline Model 2 & 10.0 & -1.0880 & 0.0110 & $-4.19 \mathrm{E}-05$ & 0.0056 & - & - & 0.9901 & 0.9893 & 0.0337 \\
\hline Model 3 & 6.0 & -1.0650 & -8.4810 & 8.5260 & 0.9989 & 0.0149 & - & 0.9850 & 0.9818 & 0.0257 \\
\hline Model 3 & 8.0 & -1.1246 & -6.5263 & 6.5656 & 0.9989 & 0.0077 & - & 0.9843 & 0.9821 & 0.0462 \\
\hline Model 3 & 10.0 & -1.0959 & -6.5424 & 6.5494 & 0.9998 & 0.0134 & - & 0.9858 & 0.9840 & 0.0486 \\
\hline Model 4 & 6.0 & -134.50 & -1.4162 & 20.247 & 0.5527 & 4.69906 & -0.0023 & 0.9842 & 0.9898 & 0.0271 \\
\hline Model 4 & 8.0 & -139.181 & -1.753 & 16.123 & 0.633 & 4.676 & -0.003 & 0.9900 & 0.9883 & 0.0293 \\
\hline Model 4 & 10.0 & -4.6521 & -5.8786 & 6.0385 & 0.9955 & 1.3803 & -0.0060 & 0.9912 & 0.9898 & 0.0299 \\
\hline
\end{tabular}

\section{Conclusions}

Adsorption in a fixed-bed column was conducted to study the effect of influent adsorbate flow rates and concentration and also the mass of the adsorbent on the adsorption process. On the basis of the experimental results, walnut shell AC was a good adsorbent for the removal of CFX from aqueous solutions in a fixed-bed adsorption column. The removal efficiency was increased with increasing the mass of adsorbent, but decreased with increasing the influent concentration and flow rate. Four mathematical models were applied to the experimental data analysis. The results indicated that the two out of four models could properly predict the adsorption breakthrough curves $\left(R^{2}>0.98\right)$.

\section{References}

[1] Al-Khateeb L., Almotiry S., Salam M.: Chem. Eng. J., 2014, 248, 191. https://doi.org/10.1016/j.cej.2014.03.023

[2] Ziylan A., Ince N.: J. Hazard. Mater, 2011, 187, 24. https://doi.org/10.1016/j.jhazmat.2011.01.057

[3] Watts C., Maycock D., Crane M., Fawell J.: Desk Based Review of Current Knowledge on Pharmaceuticals in Drinking Water and Estimation of Potential Levels. Cranfield University, Granfield 2007.

[4] Gabet-Giraud V., Miege C., Choubert J. et al:: Sci. Total Environ., 2010, 408, 4257. https://doi.org/10.1016/j.scitotenv. 2010.05.023

[5] Vieno N., Tuhkanen T., Kronberg L.: Water Res., 2007, 41, 1001. https://doi.org/10.1016/j.watres.2006.12.017

[6] Barber M., Giesecke U., Reichert A., Minas W.: Adv. Biochem. Eng. Biot., 2004, 88, 179. https://doi.org/10.1007/b99261
[7] Ahmed M., Theydan S.: Chem. Eng. J., 2012, 211, 200. https://doi.org/10.1016/j.cej.2012.09.089

[8] Dutta M., Baruah R., Dutta N., Ghosh A.: Colloid Surface A, 1997, 127, 25. https://doi.org/10.1016/S0927-7757(97)00062-9

[9] Liu W., Xie H., Zhang J., Zhang C.: Sci. China Chem., 2012, 55, 1959. https://doi.org/10.1007/s11426-011-4488-3

[10] Liu H., Liu W., Zhang J. et al.: J. Hazard. Mater., 2011, 185, 1528. https://doi.org/10.1016/j.jhazmat.2010.10.081

[11] Al-Khalisy R., Al-Haidary A., Al-Dujaili A.: Sep. Sci. Technol., 2010, 45, 1286. https://doi.org/10.1080/ 01496391003689017

[12] Dutta N., Saikia M.: Indian J. Chem. Technol., 2005, 12, 296.

[13] Omri A., Benzina M., Ammar N.: Ind. Eng. Chem., 2013, 19, 2092. https://doi.org/10.1016/j.jiec.2013.03.025

[14] Koutcheiko S., McCracken T., Kung J., Kotlyar L.: Petrol. Sci. Technol., 2007, 25, 1215. https://doi.org/10.1080/ 10916460500423395

[15] Guo J., Lua A.: J. Colloid Interf. Sci., 2002, 251, 242. https://doi.org/10.1006/jcis.2002.8412

[16] Anuradha Jabasingha S., Sheeba Varma S.: Indian Chem. Eng., 2010, 52, 230.

[17] Nowicki P., Pietrzak R., Wachowska H.: Catal. Today, 2010, 150, 107. https://doi.org/10.1016/j.cattod.2009.11.009

[18] Aksu Z., Gonen F.: Process Biochem., 2004, 39, 599. https://doi.org/10.1016/S0032-9592(03)00132-8

[19] Kananpanah S., Ayazi M., Abolghasemi H.: Pet. Coal, 2009, 51, 189.

[20] Han R., Wang Y., Zhao X. et al.: Desalination, 2009, 245, 284. https://doi.org/10.1016/j.desal.2008.07.013

[21] Chen S., Yue Q., Gao B. et al.: Bioresource Technol., 2012, 113, 114. https://doi.org/10.1016/j.biortech.2011.11.110

[22] Liao P., Zhan Z., Dai J. et al.: Chem. Eng. J., 2013, 228, 496. https://doi.org/10.1016/j.cej.2013.04.118 
[23] Tamez Uddin M., Rukanuzzaman M., Maksudur Rahman Khan M., Akhtarul Islam M.: J. Environ. Manage., 2009, 90, 3443. https://doi.org/10.1016/j.jenvman.2009.05.030

[24] Calero M., Hernainz F., Blazquez G. et al.: J. Hazard. Mater., 2009, 171, 886. https://doi.org/10.1016/j.jhazmat.2009.06.082

[25] Wang Z., Yu X., Pan B., Xing B.: Environ. Sci. Technol., 2009, 44, 978. https://doi.org/10.1021/es902775u

[26] Kananpanah S.: M.A. Thesis, University of Tehran, Tehran 2009.

[27] Foroughi-dahr M., Abolghasemi H., Esmaili M. et al.: J. Pet. Sci. Technol., 2013, 3, 35.

Received: M arch 15, 2016 / Revised: M ay 19, 2016 / Accepted: December 02, 2016

\section{АДСОРБЦЯ ЦЕФАЛЕКСИНУ В НЕРУХОМОМУ ШАРІ НА АКТИВОВАНОМУ ВУГІЛЛІ ШКАРАЛУПИ ВОЛОСЬКОГО ГОРІХА}

Анотація. Проведено видалення цефалексину (ЦФ) 3 водного розчину з використанням активованого вугілля в колониі з нерухомим шаром. Визначено криві проскоку прочесу адсорбиії ЦФ на активованому вугіллі шкаралупи волоського горіха за різної маси адсорбенту, швидкості й початкової кониенттрації ЦФ.

Ключові слова: адсорбиія цералексину, колонка з нерухомим шаром, шкаралупа волоського горіха, фізична активачія, активоване вугілля. 
